\title{
Performance, rumen characteristics and blood profile of West African dwarf goats fed varying levels of yeast (Saccharomyces cerevisiae)
}

"Adelusi, O. O., Akinbode, R. M., Adebayo, K. O. Stephen, K. M., Oluwasegun, A. S., and Onwuka, C. F. I.

Department of Animal Nutrition,

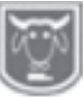

Federal University of Agriculture, Abeokuta, Nigeria.

"Corresponding author: mailto:adelusioo@,funaab.edu.ng

\begin{abstract}
$\bar{A}$ study was carried out to evaluate the effect of inclusion of yeast (Saccharomyces cerevisiae) on the performance, rumen characteristics and blood profile of West African dwarf (WAD) goats. Four (4) dietary treatments were prepared by adding $0 \mathrm{~g}, 0.5 \mathrm{~g}, 1.0 \mathrm{~g}$ and $1.5 \mathrm{~g}$ yeast to concentrate feed. Twelve (12) WAD goats with an average live weight of $10.17 \pm 0.53 \mathrm{~kg}$ were allocated to the four treatment lots in a completely randomised design and used in a feeding trial that lasted 70 days. Concentrate was fed at 3\% of body weight while Panicum maximum as the basal diet was ad libitum. Data were collected on nutrient intake, rumen fermentation and microbial ecology, blood profile and then analysed using one-way analysis of variance. Results showed that inclusion of yeast did not affect $(P>0.05)$ nutrient intake, rumen fermentation of WAD goats. Bacteria and fungi population were also not affected $(P>0.05)$ by the inclusion of yeast, however there was an increase $(P<0.05)$ in protozoa from $0.73 \times 10^{9}$ (control) to $1.33 \times 10^{9}$ (1.0g yeast). Packed cell volume $(P C V)$ of goats decreased $(P<0.05)$ when goats were fed $1.5 \mathrm{~g}$ yeast $(20.93 \%)$ compared to control $(24.37 \%)$. It can be concluded that addition of yeast to the diets of WAD goats did not affect their overall performance, increased population of rumen protozoa and reduced blood packed cell volume.
\end{abstract}

Keywords: Yeast, goats, nutrient, rumen, blood.

\section{Introduction}

The nutritional value of feed materials available to livestock is closely dependent on the extent of utilization during digestion in the body of the animal, and the ability of dietary components to work together holistically. Digestive processes in the rumen can be manipulated through the addition of direct-fed microbial which enhances feed digestion, to improve the performance of animals and to boost the health status of animal (Robinson and Erasmus, 2009). Further, probiotics enhance rumen microbial ecosystem (Abd El-Ghani, 2004), nutrient absorption and feed conversion rate (Antunovic et al., 2006; Whitley et al., 2009) leading to better production performance of animals in which they are administered.

The use of yeast (Saccharomyces cerevisiae) as a dietary supplement carried in a culture has been suggested as a useful tool to stabilize ruminal fermentation (William et al., 1991) and it has been found to have a number of effect in the rumen including increased $\mathrm{pH}$, altered volatile fatty acids concentration, increased number of cellulolytic bacteria (William et al. 1991; Callaway and Martin, 1997) and increased rate or extent of ruminal fibre digestion (Callaway and Martin, 1997). Yeasts and yeast products used in ruminant nutrition to manipulate rumen fermentation and improved animal performance have however yielded varied results in terms of 


\section{West African dwarf goats fed varying levels of yeast (Saccharomyces cerevisiae)}

performance. These difference may depend on many factors such as diet composition, forage to concentrate ratio, type of forage fed, yeast dose feeding strategy and stage of lactation (Robinson and Garrett, 1999). Addition of $S$. cerevisiae to the diet stimulates cellulolytic bacteria e.g. Ruminococcus albus and Fibrobacter succinogens (Chaucheyras et al., 1997) and improves the digestibility of structural carbohydrates in the rumen. The increased bacteria count is probably the result of improved anaerobic status of the rumen (Ding et al., 2014). It has also been shown that live yeast and yeast culture supplementation may increase feed intake and milk production of dairy cows (Dann et al., 2000), however several other studies have either reported contrasting or fuzzy effects of yeast supplementation on rumen fermentation and blood status of livestock animals (Haddad and Goussous, 2004; Kawas et al. 2007b; Ding et al., 2008). So this study therefore evaluated the effect of varying level of yeast on rumen fermentation and microbiology of West African dwarf goat.

\section{Materials and methods}

The experiment was conducted at the Small Ruminant Research Unit of the Directorate of University Farms, Federal University of Agriculture, Abeokuta, Nigeria. The site is located in the derived savannah zone of the south-western part of Nigeria on latitude $7^{\circ} 13^{\prime} 49.46 \square \mathrm{N}$ and longitude $3^{\circ} 25^{\prime} 11.98 \square \mathrm{E}$ (Google Earth, 2017). The climate is humid with a mean annual rainfall of $1,037 \mathrm{~mm}$ and mean temperature and humidity of $31.7^{\circ} \mathrm{C}$ and $83 \%$, respectively.

\section{Experimental design and animal management}

Twelve (12) West African dwarf goats with an average live weight of $10.17 \pm 0.53 \mathrm{~kg}$ were used for the study. The goats were housed intensively in well ventilated pens with wood-slatted floors. The experiment was set up in a completely randomized design (CRD) with four levels of yeast $(0 \mathrm{~g}$, $0.5 \mathrm{~g}, 1.0 \mathrm{~g}$, and $1.5 \mathrm{~g}$ ) added to the concentrate feed (cassava peel $(30 \%)$, dried brewers grain (34\%), rice bran (30\%), bone meal (4\%) and salt (2\%)). Each treatment had three (3) replicates each. The feeding trial lasted 70 days with concentrate being served by 0700 hours to the animals at 3\% of their body weight and Panicum maximum (basal diet) and clean water was provided for ad libitum intake. Feeds were sampled every week, and respective samples were pooled after oven-drying for chemical analysis.

Feed intake and weight gain measurements

Feed intake and refusal were recorded and the goats were weighed bi-weekly throughout the experimental period.

\section{Chemical analysis offeed}

Samples of concentrate and Panicum feed served were collected, oven dried, ground and were pooled together. The pooled samples were analysed in the laboratory to determine the chemical composition according to methods of AOAC (2000).

\section{Collection and analyses of rumen fluid}

On the last day of the trial, rumen fluid was collected from each buck at 0 and 6 hours after feeding via the oesophagus through the use of a suction tube. About $100 \mathrm{~mL}$ of rumen fluid was taken into aseptic tubes, filtered through four layers of cheese cloth, were divided into three parts, and kept in sample bottles for fermentation and microbial analyses. The determination of rumen ammonia nitrogen was carried out according to the method described by Lanyansunya et al. (2007). Volatile fatty acids (lactic acid, propionic, acetic and butyric acids) were determined by using the modified protocol of potentiometric titration system (Siedlecka et al., 2008). The second portion of the rumen fluid was 


\section{Adelusi, Akinbode, Adebayo, Stephen, Oluwasegun and Onwuka}

divided into two parts. A part was fixed with $10 \%$ formalin solution in sterilized $0.9 \%$ saline solution. The total direct count of bacteria, protozoa and fungal zoospores was made by the methods of Galyean (1989).

\section{Collection of blood samples and analyses}

Blood samples (approximately $10 \mathrm{ml}$ ) were collected from each goat early in the morning before feeding at the start and end of the trial via jugular vein puncture using hypodermic syringes. Five millilitres was drawn into a heparinized tube to prevent coagulation while the remaining $5 \mathrm{ml}$ was introduced into another set of bottles without anticoagulants, and all the samples were stored at $-4{ }^{\circ} \mathrm{C}$ for subsequent analysis.

The packed cell volume (PCV) of blood was measured in fresh ethylene diamine tetra acetic acid (EDTA) anti-coagulant samples within $24 \mathrm{~h}$ of collection using the microhaematocrit method. Haemoglobin concentration was assessed using Sahl's (acid haematin) method (Benjamin, 1978). Red blood cell (RBC) was measured with the aid of Neubauer counting chamber (haemocytometer). Blood smears were used for total thrombocyte, total white blood cell (WBC) counts (Dzowela et al., 1995) and WBC differential relative and absolute counts. Differential relative and absolute counts were classified as lymphocytes, neutrophils, eosinophils, basophils and monocytes. Plasma glucose was measured using the enzymatic glucose oxidase method (Bauer et al., 1974). Mean corpuscular haemoglobin $(\mathrm{MCH})$ and mean corpuscular haemoglobin concentration (MCHC) values were calculated from packed cell volume (PCV), haemoglobin $(\mathrm{Hb})$ and $\mathrm{RBC}$ values (Jain, 1986). Total serum protein was measured using the biuret method. Alanine aminotransferase (ALT) was analysed spectrophotometrically using commercially available diagnostic kits (Randox ${ }^{\circledR}$ test kits). Serum albumin was determined using bromocresol purple method while serum creatinine (SC) was determined with the principle of Jaffe reaction as described by Bonsnes and Taussky (1945).

\section{Statistical analysis}

The data from this experiment were analysed separately using one-way analysis of variance option of the IBM SPSS Statistics software (Version 20; IBM SPSS 2011). Treatment means were statistically compared using Duncan's Multiple Range Test (Duncan, 1955) and significant differences were declared at $P<0.05$.

\section{Results}

Table 1 shows the effect of yeast (Saccharomyces cerevisiae) inclusion on the performance and nutrient intake of West African dwarf goats. The inclusion of yeast in the diets did not affect $(\mathrm{P}>0.05)$ the total and respective nutrients intake of WAD goats. However, lower $(\mathrm{P}<0.05)$ weight gain was recorded when the animals were fed $1.0 \mathrm{~g}$ yeast $(0.17 \mathrm{~kg})$ and $1.5 \mathrm{~g}$ yeast $(0.40 \mathrm{~kg})$ compared to $1.13 \mathrm{~kg}$ and $1.27 \mathrm{~kg}$ obtained with inclusion of $0 \mathrm{~g}$ and $0.5 \mathrm{~g}$ yeast, respectively.

Table 1 : Performance and nutrient intake of West African dwarf goats fed varying levels of yeast (Saccharomyces cerevisiae)

\begin{tabular}{llllllc}
\hline \multicolumn{7}{c}{ Levels of yeast inclusion } \\
Parameter & $0 \mathrm{~g}$ & $0.5 \mathrm{~g}$ & $1.0 \mathrm{~g}$ & $1.5 \mathrm{~g}$ & SEM & P value \\
\hline Total intake $(\mathrm{kg})$ & 106.87 & 106.08 & 103.36 & 105.43 & 0.667 & 0.31 \\
Dry matter intake $(\mathrm{kg})$ & 97.70 & 96.96 & 94.47 & 96.37 & 0.606 & 0.30 \\
Crude protein intake $(\mathrm{kg})$ & 9.63 & 9.55 & 9.30 & 9.49 & 0.063 & 0.34 \\
NDF intake $(\mathrm{kg})$ & 48.41 & 48.04 & 46.81 & 47.74 & 0.306 & 0.32 \\
ADF intake $(\mathrm{kg})$ & 25.64 & 25.42 & 24.77 & 25.60 & 0.166 & 0.34 \\
Final weight $(\mathrm{kg})$ & 12.53 & 12.93 & 10.83 & 12.00 & 0.783 & 0.84 \\
Weight gain $(\mathrm{kg})$ & $1.13^{\mathrm{a}}$ & $1.27^{\mathrm{a}}$ & $0.17^{\mathrm{b}}$ & $0.40^{\mathrm{ab}}$ & 0.180 & 0.02 \\
\hline NDF: Neutral detergent fibre & ADF: Acid detergent fibre & & & &
\end{tabular}




\section{West African dwarf goats fed varying levels of yeast (Saccharomyces cerevisiae)}

Table 2 shows the effect of dietary inclusion of yeast on the rumen fermentation of WAD goats. The result shows that lactic acid, acetic acid, propionic acid, butyric acid and rumen ammonia nitrogen $\left(\mathrm{NH}_{3}-\mathrm{N}\right)$ were not influenced $(p>0.05)$ by the inclusion of yeast.

Table 2: Rumen fermentation of West African dwarf goats fed varying levels of yeast (Saccharomyces cerevisiae)

\begin{tabular}{lllllll}
\hline & \multicolumn{7}{c}{ Levels of yeast inclusion } & & \\
\cline { 2 - 5 } Parameters & $0 \mathrm{~g}$ & $0.5 \mathrm{~g}$ & $1.0 \mathrm{~g}$ & $1.5 \mathrm{~g}$ & SEM & P value \\
\hline Lactic acid (\%) & 1.01 & 1.14 & 1.28 & 1.22 & 0.06 & 0.476 \\
Acetic acid (\%) & 0.68 & 0.76 & 0.86 & 0.81 & 0.04 & 0.476 \\
Propionic acid (\%) & 0.45 & 0.51 & 0.57 & 0.54 & 0.03 & 0.476 \\
Butyric acid (\%) & 0.07 & 0.08 & 0.09 & 0.08 & 0.00 & 0.476 \\
$\mathrm{NH}_{3}-\mathrm{N}(\mathrm{mg} / \mathrm{dL})$ & 3.46 & 3.57 & 2.55 & 3.35 & 0.22 & 0.382 \\
\hline
\end{tabular}

The rumen ecology of WAD goats fed yeast is presented in Table 3 . The results showed that bacteria and fungi population were not affected $(p>0.05)$ by the treatment.
Protozoa population increased $(\mathrm{p}<0.05)$ with the inclusion of $1 \mathrm{~g}$ yeast $\left(1.33 \times 10^{9}\right)$ compared to the control group fed $0 \mathrm{~g}$ yeast $\left(0.73 \times 10^{9}\right)$.

Table 3: Rumen microbial population of West African dwarf goats fed varying levels of yeast (Saccharomyces cerevisiae)

\begin{tabular}{lllllll}
\hline & \multicolumn{9}{c}{ Levels of yeast inclusion } & & \\
\cline { 2 - 5 } Microbes & $0 \mathrm{~g}$ & $0.5 \mathrm{~g}$ & $1.0 \mathrm{~g}$ & $1.5 \mathrm{~g}$ & SEM & P value \\
\hline Bacteria $\left(\mathrm{cfu} / \mathrm{ml} \times 10^{12}\right)$ & 0.50 & 0.73 & 1.10 & 0.80 & 0.09 & 0.20 \\
Fungi, $\times 10^{6}$ & 0.03 & 0.00 & 0.00 & 0.00 & 0.01 & 0.17 \\
Protozoa, $\times 10^{9}$ & $0.73^{\mathrm{b}}$ & $0.63^{\mathrm{b}}$ & $1.33^{\mathrm{a}}$ & $0.70^{\mathrm{b}}$ & 0.09 & 0.01 \\
\hline ab & Means on the same row with the different superscripts are significantly different $(\mathrm{P}<0.05)$ & &
\end{tabular}

The effect of dietary inclusion of yeast on the haematology values of WAD are presented in Table 4. Values obtained for packed cell volume (PCV) decreased $(\mathrm{P}<0.05)$ when goats were fed $1.5 \mathrm{~g}$ of yeast $(20.93 \%)$ when compared with the goats maintained in the control group $(24.37 \%)$. Result for other parameters showed that there were no significant $(\mathrm{P}>0.05)$ differences among the various treatments. The serum biochemistry indices of WAD goats fed dietary inclusion of yeast are presented in Table 5. Results showed that there were no significant $(\mathrm{P}>0.05)$ differences among the various treatments.

\section{Discussion}

The result obtained with the utilization of yeast in diets of animals is inconsistent and vary from one specie to another. The dry matter intake of cattle has been reportedly improved by the inclusion of yeast (Mutsvangwa et al., 1992), however in this study, the intake of goats were not affected by the additive. Observation in this study was similar to the those of Kawas et al. (2007a) and Mikulec et al. (2010) which supplemented yeast to the diets of fattening and finishing lambs. Reduced weight gain was observed with the inclusion of yeast to the diets of goats, other studies however have revealed varied effects of yeast inclusion on the weight gain of small ruminants. Haddad and Goussous (2004) observed improved weight gain after supplementing yeast to finishing sheep diets, while Kawas et al. (2007b) reported that yeast supplementation did not affect the growth performance of lambs. 
Adelusi, Akinbode, Adebayo, Stephen, Oluwasegun and Onwuka

Table 4: Haematology indices of West African dwarf goats fed varying levels of yeast (Saccharomyces cerevisiae)

\begin{tabular}{|c|c|c|c|c|c|c|}
\hline \multirow[b]{2}{*}{ Parameter } & \multicolumn{4}{|c|}{ Levels of yeast inclusion } & \multirow[b]{2}{*}{ SEM } & \multirow[b]{2}{*}{$\mathrm{P}$ value } \\
\hline & $0 \mathrm{~g}$ & $0.5 \mathrm{~g}$ & $1.0 \mathrm{~g}$ & $1.5 \mathrm{~g}$ & & \\
\hline Packed cell volume (\%) & $24.37^{\mathrm{a}}$ & $23.27^{\mathrm{ab}}$ & $25.37^{\mathrm{a}}$ & $20.93^{b}$ & 0.638 & 0.05 \\
\hline Red blood cells $\left(\times 10^{12 / \mathrm{L}}\right)$ & 14.00 & 14.56 & 15.28 & 14.09 & 0.354 & 0.63 \\
\hline Haemoglobin $(g / l)$ & 9.43 & 9.70 & 10.53 & 9.03 & 0.273 & 0.28 \\
\hline $\mathrm{MCV}(\mathrm{f} / \mathrm{L})$ & 16.30 & 16.00 & 16.67 & 15.03 & 0.283 & 0.21 \\
\hline $\mathrm{MCHC}(\mathrm{g} / \mathrm{L})$ & 41.37 & 41.60 & 41.47 & 42.97 & 0.526 & 0.74 \\
\hline $\mathrm{MCH}(\mathrm{pg})$ & 6.67 & 6.60 & 6.83 & 6.37 & 0.077 & 0.19 \\
\hline $\mathrm{WBC}\left(\times 10^{9} / \mathrm{L}\right)$ & 20.90 & 19.47 & 14.23 & 21.57 & 1.283 & 0.16 \\
\hline Lymphocytes $\left(\times 10^{9} / \mathrm{L}\right)$ & 41.33 & 39.33 & 35.00 & 34.00 & 1.836 & 0.49 \\
\hline Neutrophils (\%) & 54.00 & 55.67 & 61.00 & 62.00 & 1.996 & 0.46 \\
\hline Eosinophils (\%) & 1.33 & 1.67 & 1.33 & 1.67 & 0.230 & 0.94 \\
\hline Monocytes (\%) & 3.00 & 3.33 & 2.67 & 2.33 & 0.386 & 0.86 \\
\hline Basophils (\%) & 0.33 & 0.00 & 0.00 & 0.33 & 0.112 & 0.59 \\
\hline
\end{tabular}

Table 5: Serum biochemistry indices of West African dwarf goats fed varying levels of yeast (Saccharomyces cerevisiae)

\begin{tabular}{lllllll}
\hline & \multicolumn{7}{c}{ Levels of yeast inclusion } \\
\cline { 2 - 5 } Parameter & $0 \mathrm{~g}$ & $0.5 \mathrm{~g}$ & $1.0 \mathrm{~g}$ & $1.5 \mathrm{~g}$ & SEM & P value \\
\hline Total protein $(\mathrm{g} / \mathrm{dL})$ & 12.80 & 10.83 & 8.07 & 4.63 & 1.391 & 0.18 \\
Albumin $(\mathrm{g} / \mathrm{L})$ & 2.33 & 2.20 & 2.36 & 2.06 & 0.181 & 0.95 \\
ALT $(\mathrm{U} / \mathrm{L})$ & 8.00 & 9.67 & 4.00 & 4.00 & 1.505 & 0.49 \\
Urea $(\mathrm{mg} / \mathrm{dl})$ & 26.23 & 21.55 & 24.33 & 12.00 & 2.525 & 0.19 \\
Creatinine $(\mathrm{mg} / \mathrm{dL})$ & 1.75 & 5.56 & 4.39 & 3.43 & 0.789 & 0.42 \\
Glucose $(\mathrm{mg} / \mathrm{dL})$ & 15.33 & 15.67 & 16.33 & 14.40 & 0.821 & 0.90 \\
Total bilirubin $(\mathrm{mg} / \mathrm{dL})$ & 0.64 & 0.70 & 1.01 & 1.21 & 0.129 & 0.39 \\
\hline
\end{tabular}

ALT: Alanine aminotransferase

Indicators of rumen fermentation like VFA profile and rumen ammonia nitrogen values were not influenced by the inclusion of yeast in the diets of WAD goats. This agreed with the study of Chedemama and Offer (1990) and Özsoy et al. (2013) that yeast does not impact volatile fatty acids concentration and fermentation patterns. Also similar to the present study, was the observation that yeast culture did not affect the proportions of acetate and propionate in the rumen (Moya et al., 2009). Ding et al. (2008) reported that the effects of yeast supplementation on rumen fermentation parameters are hardly predictable. The inconsistent results may be related to the differences in chemical composition of diets and intake levels.

Yeasts are chemo-organotrophs that utilize organic compounds as a source of energy, and this could mean that the extra volatile fatty acids generated through additional degradation by the probiotic yeast was utilized for their proliferation. Williams et al. (1991) clarified that through the degradation of lyotropic carbohydrates in the rumen, yeast cultures regulate the rate of fermentation. It also reported that by stimulating the increased population of lactate-utilizing bacteria, yeasts facilitate the stabilization of rumen $\mathrm{pH}$ and mitigate its frequent oscillations during the day. This 


\section{West African dwarf goats fed varying levels of yeast (Saccharomyces cerevisiae)}

can be responsible for the numerical increase observed in the amount of lactate in the rumen of the goats, though not significantly varied across the treatments. A sharper increase in the level of inclusion might see a different result in terms of significance as there would likely be more production of lactic acid as the number of lactate-utilizing bacteria increase, since probiotic generally contributes to the microbial balance of the gut (Antunovic et al., 2005).

It has been reported that yeast culture stimulates growth of cellulolytic bacteria and improves anaerobiosis in the rumen (Wallace, 1994). Although there was a numerical increase in the rumen bacteria count of goats in this study, there was however, no sufficient variation among the treatments to ensure an agreement with observations recorded in this earlier report. The increase observed in rumen protozoa population as the dietary yeast increased was in agreement with the study of Plata et al. (1994) that the protozoa values were elevated with the inclusion of $S$. cerevisiae in animal diet. There were studies that obtained contrary observations. For example, Angeles et al. (1995) reported a reduction in protozoa population while the numbers remain unchanged in the experiments conducted by Miranda et al. (1996).

The levels and concentration of blood metabolites serve as an indicator of the metabolic health status of the animal, and can help in identifying pathological situations. Inclusion of yeast in diets of WAD goats resulted in reduced PCV. The protein utilization of the goats in this study were affected by dietary inclusion of yeast, as one of the clinically beneficial methods in assessing the protein status is the PCV of the blood. This also helps to possibly forecast the degree of protein supplementation in goats (Daramola et al.,
2005). The values recorded for serum urea values were higher than the reference range (Merck, 2017), except for the goats fed $1.5 \mathrm{~g}$ yeast. This high values could be attributed to an imbalance in amino acids, indicating that the diet had lower biological value. According to Daramola et al. (2005), increased catabolism of amino acids when protein of lower biological value is fed is responsible for high urea values.

Elevated creatinine levels (though not significantly different) were observed with the inclusion of yeast compared to the animals in the control group. These creatinine values however, mean a presence of factors in the feed which portray poor quality and also negatively affect the stability and normal working of the kidney. Wuanor and Carew (2018) reported that serum creatinine level is a useful indicator of glomerular filtration in the kidney; normal values indicate animals are not in a catabolism situation and kidney function is improved.

\section{Conclusion and recommendations}

From the results of this study, it can be concluded that the addition of yeast to the diet of WAD goats affected the values obtained for weight gain and some blood metabolites. Yeast did not affect the rumen fermentation parameters measured. Although bacteria and fungi population were also not affected by the inclusion of yeast, the increase observed in the protozoa population could have implications for methane production in the rumen. Further studies are therefore recommended to investigate higher levels of yeast inclusion and the interaction between yeast and protozoa with its bearing on feed utilization.

\section{References}

A. O. A. C. 2000. Official Methods of Analysis 17th ed. Association of 


\section{Adelusi, Akinbode, Adebayo, Stephen, Oluwasegun and Onwuka}

Official Analytical Chemists, Washington DC.

Abd El Ghani, A. A. 2004. Influence of supplementation with yeast (Saccharomyces cerevisiae) on performance of Zaraibi goats. Small Ruminant Res. 52:223-229

Angeles, C., Mendoza, M., Cobos, P., Crosby, G., Castrejon, P. 1998. Comparison of two commercial yeast cultures (Saccharomyces cerevisiae) on ruminal fermentation and digestion in sheep fed on corn-stover diet. Small Ruminant Res. 31:45-50.

Antunovic, Z., Speranda, M., Amidzic, D., Seric, V., Steiner, Z., Domacinovic, $\mathbf{N}$. and Boli, $\mathbf{F}$. 2006. Probiotic application in lamb's nutrition. Krmiva 48: 175180.

Bauer, T. D., Ackermann, P. G., Toro, G. 1974. Methods in clinical chemistry. Clinical laboratory methods. The C.V. Mosley Company, Saint Louis, p. 946.

Benjamin, M. M. 1978. Outline of Veterinary Clinical Pathology, 2nd edition. Iowa State University Press, Iowa, 35-105.

Bonsnes, R. W., Taussky, H. H. 1945. On the colorimetric determination of creatinine by the Jaffe reaction. Journal of Biological Chemistry, 158, 581-591.

Callaway, E. S. and Martin, S.A. 1997. Effects of a Saccharomyces cerevisiae culture on ruminal bacteria that utilize lactates and digest cellulose. J. Dairy Sci. 80:2035-2044.

Chaucheyras, F., Millet, L, MichaletDoreau, B., Font, G., Bertin, G. 1997. Effect of the addition of Levuvell ${ }^{\circledR}$ SC on the rumen microflora of sheep during adaptation to high starch diets. Reproduction Nutrition Development, 37(1):82-83.

Chedemama, Y. and Offer, N. W. 1990. The effect of dietary inclusion of yeast culture on digestion in the sheep. Animal production 50,483489.

Dann, H. M., Drackley, J. K., Mccoy, G. C., Hutjens, M. F. and Garrett, J. E. 2000. Effects of yeast culture (Saccharomyces cerevisiae) on prepartum intake and postpartum intake and milk production of Jersey cows. J. Dairy science 83:123-127.

Daramola, J. O., Adeloye, A. A., Fatoba, T.A., Soladoye, A. O. 2005. Haematological and biochemical parameters of West African dwarf goats. Livestock Research for Rural Development 17(8):28-38.

Ding, G. J., Chang, Y., Zhou, Z. M., Ren, L. P. and Meng, Q. X. 2014. Effect of Saccharomyces cerevisiae on alfafa nutrient degradation characteristics and rumen microbial populations of steers fed diets with different concentrate-to forage ratios. Journal of Animal Science Biotechnology 5:24-40.

Ding, G. J., Zhou Z. M., Ren L. P., Meng Q.X. 2008. Effect of monensin and live yeast supplementation on growth performance, nutrient digestibility, carcass characteristics and ruminal fermentation parameters in lambs fed steamflaked corn-based diets. AsianAust. J. Anim. Sci. 21, 547-554.

Duncan, D. B. 1955. Multiple range and multiple F-test. Biometrics 11, pp. $1-42$.

Dzowela, B. Hove, H. L. and Mafongoya, P. L. 1995. Effect of drying method 
West African dwarf goats fed varying levels of yeast (Saccharomyces cerevisiae)

on chemical composition and in vitro digestibility of multipurpose tree and shrub fodder. Tropical Grassland 29:263-269.

Galyean, M. 1989. Laboratory Procedure in Animal Nutrition Research. Department of Animal and Life Science, New Mexico State University, Las Cruces. $107-122 p p$

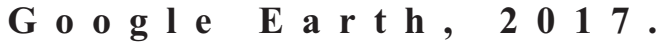
http://www.google.earth

Haddad, S. G. and Goussous, S. N. 2004. Effects of yeast culture supplementation on nutrient intake digestibility and growth performance of Awassi lambs. Anim. Feed Sci. Technol. 118, 343348.

IBM SPSS 2011. Statistics Version 20. IBM Corporation.

Jain, N.C. 1986. Schalman's Veterinary Haematology, 4th edition. Lea and Babings, Philadelphia, 208-224

Kawas, J. R., García-Castillo, R., Fimbres-Durazo, H., GarzaCazares, F., Hernández-Vidal, G., Olivares-Sáenz, E. and Lu, C. D. 2007a. Effects of sodium bicarbonate and yeast on nutrient intake, digestibility, and ruminal fermentation of light-weight lambs fed finishing diets. Small Ruminant Research 67, 149-156.

Kawas, J. R., García-Castillo, R., GarzaCazares, F., Fimbres-Durazo, H., Olivares-Sáenz, E., HernándezVidal, G. and Lu, C. D. 2007b. Effects of sodium bicarbonate and yeast on productive performance and carcass characteristics of lightweight lambs fed finishing diets. Small Ruminant Research 67, 157163.

Lanyansunya, T.P, Wang, H., Kariuki, S., Mukisira, E., Abdulrasak, S.,
Kibitok, N. and Ondiek, J. 2007. The potential of Commelina benghalensis as forage for ruminants. Animal Feed Science and Technology, 144: 185-195.

Merck, 2017. Merck Veterinary Manual. http://www.merckmanuals.com/vet/ appendixes

Mikulec, Z., Mašek, T., Habrun, B. and Valpotić, H. 2010. Influence of live yeast cells (Saccharomyces cerevisiae) supplementation to the diet of fattening lambs on growth performance and rumen bacterial number. Vet. Arhiv 80 (6), 695-703.

Miranda, R. L. A., Mendoza, M. G. D., Barcena-Grama, J. R., Gonzalez, M. S. S., Ferrara, C. M. E., Cobo, P. M. A., 1996. Effect of Saccharomyces cerevisiae or Aspergillus oryzae cultures and NDF level on parameter of ruminal fermentation. Animal science 74, 563-566.

Moya, D., Calsamiglia, S., Ferret, A., Blanch, M., Fandino, J. I., Castillejos L., Yoon I. 2009. Effects of dietary changes and yeast culture (Saccharomyces cerevisiae) on rumen microbial fermentation of Holstein heifers. $J$. Anim. Sci., 87, 2874-2881.

Mutsvangwa, T., Edwards, I. E., Topps, J.H., Paterson, G. F. M. 1992. The effect of dietary inclusion of yeast culture (Yea-Sacc) on patterns of rumen fermentation, food intake and growth of intensively fed bulls. Animal Production 55, 35-40.

Özsoy, B., Yalçin, S., Erdoğan, Z., Cantekin, Z., Aksu, T. 2013. Effects of dietary live yeast culture on fattening performance on some blood and rumen fluid parameters in goats. Revue Méd. Vét. 164 (5) 263-271. 
Plata, P. F., Mendoza, M. G. D., BarcenaGama, J. R., Gonzalez, M. S. 1994. Effect of a yeast culture (Saccharomyces cerevisiae) on neutral detergent fibre digestion in steers fed oat straw based diets. Anim. Feed Sci. Technol. 49, 203210.

Robinson, P. H and Erasmus, L. J. 2009. Effect of analysable diet components on response of lactating dairy cows to Saccharomyces cerevisiae based yeast product: A systematic review of the literature. Anim. Feed Sci. Technol. 149:185-198.

Robinson, P. H. and Garrett, J. E. 1999. Effects of yeast culture (Saccharomyces cerevisiae) on adaptation of cows to postpartum diets and on lactation performance. J. Anim. Sci. 77:988-999

Siedlecka, E. M., Kumirska, J., Ossowski, T., Glamowski, P., Gołębiowski, M., Gajdus, J., Kaczyński, Z. and Stepnowski, P. 2008. Determination of Volatile Fatty Acids in Environmental Aqueous Samples. Polish Journal of Environmental Studies, 17(3): 351-356

Wallace, R.J. 1994. Ruminal microbiology, biotechnology and ruminant nutrition: progress and problems. J. Anim. Sci. 72, 29923003 .
Whitley, N. C., Cazac, D., Rude, B. J., Jackson O'Brien, D., Parveen, $S$. 2009. Use of commercial probiotic supplement in meat goats. Journal of Animal Science 87:723-728.

Williams, P. E., Tait, V. C. A. G. Innes, G. M. and Newbold, C. J. 1991. Effects of the inclusion of yeast culture (Saccharomyces cerevisiae plus growth medium) in the diet of dairy cows on milk yield and forage degradation and fermentation patterns in the rumen of steers. J. Anim. Sci. 69:30163026.

Wuanor, A. A. and Carew, S. N. 2018. Feed efficiency and blood profiles of West African dwarf goats fed Pleurotus tuber-regium biodegraded rice straw and maize offal -brewer yeast slurry mixture. Journal of Agriculture and Ecology Research International, 14(1): 1-10.

Received: $25^{\text {th }}$ July, 2018

Accepted: $21^{\text {st }}$ December, 2018 